
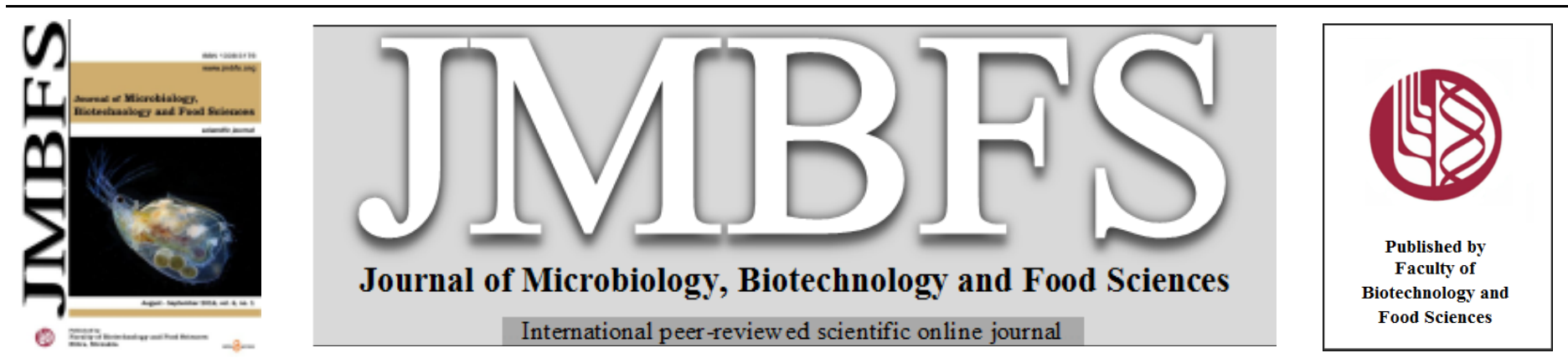

\title{
COMPARATIVE CHARACTERIZATION OF POSSIBILITIES OF USING LOW-ESTERIFIED AND AMIDATED PECTIN IN FERMENTED DAIRY PRODUCTS
}

\author{
Radka Vlaseva ${ }^{1}$, Mihaela Ivanova ${ }^{1}$, Mima Hadjikinova $^{2}$, Dimitar Hadjikinov ${ }^{4}$, Valentina Dobreva ${ }^{2}$, Nadezhda Petkova $^{3}$, Panteley \\ Denev ${ }^{3}$, Dimitar Dimitrov ${ }^{5 *}$
}

$\operatorname{Address}(e s)$ :

${ }^{1}$ Department of Technology of Milk and Dairy Products, University of Food Technologies, 26 Maritza Blvd., 4002 , Plovdiv, Bulgaria, phone number: +35932603770 ${ }^{2}$ Department of Environmental Engineering, University of Food Technologies, 26 Maritza Blvd., 4002, Plovdiv, Bulgaria, phone number: +35932603761

${ }^{3}$ Department of Organic Chemistry, University of Food Technologies, 26 Maritza Blvd., 4002 , Plovdiv, Bulgaria, phone number: +35932603697

${ }^{4}$ Department of Technology of Sugar, Confectionery, Starch and Starch hydrolysates, University of Food Technologies, 26 Maritza Blvd., 4002, Plovdiv, Bulgaria, phone number: +35932603726

${ }^{5}$ Department of Enology and Chemistry, Institute of Viticulture and Enology, Kala Tepe 1 str., 5800 , Pleven, Bulgaria, phone number: +359885540245

*Corresponding author: dimitar_robertov@abv.bg

doi: 10.15414/jmbfs.2016.6.1.649-651

\section{ARTICLE INFO}

Received 4. 2. 2016

Revised 2.3. 2016

Accepted 6. 3. 2016

Published 1. 8. 2016

Regular article

open $\mathcal{O}_{\text {ACCESS }}$

\section{ABSTRACT}

The possibilities of using low-esterified amidated pectin isolated from Bulgarian plant cultures have been studied. The comparison between pectin extracted from celery and commercial low-esterified amidated pectin showed that celery pectin can be used successfully for preparation of functional fermented dairy products enriched with soluble dietary fibers. It was found that the addition of amidated pectin extracted from celery in an amount exceeding $1 \mathrm{~g} \cdot \mathrm{kg}^{-1}$ deteriorates the organoleptic characteristics of the product, but viscosity of the produced experimental dairy product remained unchanged in comparison with that of the control sample. Therefore, it is recommended that the concentration of low-esterified amidated pectin used in preparation of dairy products do not exceed the limits established in this study.

Keywords: Yoghurt, amidated pectin, rheology, celery

\section{INTRODUCTION}

Yogurts are characterized by a high biological and health potential associated with their composition and the presence of selected active microorganisms (Beena, 2000).

It is well known that dietary fibers are a physiologically important component of food and have a positive impact on the digestive tract and various functional processes in the human body (Ramaswamy and Basak, 1992). Dairy products do not contain fibers and it is appropriate to be enriched with these polysaccharides to enhance their biological value (Khurana and Kanawjia, 2007).

Pectins are the most commonly used fibers in the manufacture of food products. It is known that these natural polymers are characterized by certain technological properties and possess distinct functional and health benefits (Combo et al., 2011). The addition of pectins in the manufacture of fermented dairy products is based on their ability to interact with the casein micelles in milk in the presence of calcium ions, forming stable gel structures in the $\mathrm{pH}$ range of 2.5 to 4.5 (Maroziene and Kruif , 2000).

Amidated pectin E 440 is a modified form of pectin, highly sensitive to the concentration of calcium ions in regard to its stabilizing properties. The use of low-esterified amidated pectin to form protein gel structures in the manufacture of foods requires a high concentration of calcium ions in the medium (Uresti $\boldsymbol{e t}$ al., 2003).

The aim of this study is to make a comparative evaluation of technological possibilities to obtain fermented dairy products with the addition of low-esterified amidated pectin isolated from Bulgarian crop plants.

\section{MATERIAL AND METHODS}

\section{Materials}

The experiments were carried out with raw cow's milk, whose organoleptic, physicochemical and microbiological properties were evaluated according to the requirements of Regulation (EC) No 853/2004.

The milk fat content was standardized to $36 \pm 1 \mathrm{~g} \cdot \mathrm{kg}^{-1}$.

A starter culture for yogurt containing specific strains (Lactobacillus delbrueckii subsp. bulgaricus and Streptococcus thermophilus) was used in a quantity of 20 g.kg-1.

To perform the experiment, the following materials were used: low-esterified amidated pectin isolated from celery with degree of esterification (DE) $-28 \%$, anhydrouronic content $-68 \%$ and degree of amidation $-28 \%$ and commercial pectin Pe Amid CM 020 (Herbstreith \& Fox, Germany), degree of esterification $27 \%$, anhydrouronic content $-70 \%$, degree of amidation $-25 \%$.

\section{Methods}

The classical technology for production of yogurt was applied in laboratory conditions (Kondratenko and Simov, 2003).

Pectin can be incorporated in the milk as a solution or in a dry state, in combination with a certain amount of sugar (Vlaseva, 2014), before pasteurization or as pre-pasteurized solution before inoculation with the yoghurt starter cultures. In the present study pectin was incorporated before the pasteurization process.

The dispersion of pectin with $60 \mathrm{~g} . \mathrm{kg}^{-1}$ sugar was conducted at $80^{\circ} \mathrm{C}$ for $5 \mathrm{~min}$ at speed $9900 \mathrm{~g}$, in a dry state. The amounts of added pectin were 1.2 and $3 \mathrm{~g} \cdot \mathrm{kg}^{-1}$ by Polytron $®$ PT45-80 (Kinematika, Switzerland) with technical characteristics $220 \mathrm{~V} ; 50 \mathrm{~Hz} ; 1600 \mathrm{~W}$;

The change in the amount of lactose and its biochemical transformation to lactic acid during fermentation was defined by:

- Active acidity $(\mathrm{pH})$, potentiometrically measured with a 7110 WTW (Germany) $\mathrm{pH}-$ meter

- Titratable acidity, measured according to ISO 6091:2010 (IDF 86:2010); 
The structural characteristics of the coagulum after manufacture were determined by:

- the amount of separated serum, which characterizes the stabilizing capacity of the added pectins, determined by centrifugal test: $10 \mathrm{~cm}^{3}$ of the prepared sample was centrifuged at $2400 \mathrm{~g}$, immediately after coagulation (Kuncheva et al. 2007) by Centrifuge - $\mathrm{CH} 90-2 \mathrm{~A}$;.

- the viscosity of yoghurt was determined by a rheoviscometer, at a temperature of $25^{\circ} \mathrm{C}$ by a Rheotest 2 (Germany) rotational viscometer;

- the organoleptic characterization was made according to the Bulgarian State Standard (BSS) 12:2010. In all analyzed samples the packaging was graded 10 points (the maximum score for this indicator).

\section{Statistical analysis}

The statistical analysis was performed using Microsoft Excel 2010 (ANOVA) Multiple comparisons were made by the LSD method. The results are presented as means value $\pm \operatorname{SD}(\mathrm{n}=3)$

\section{RESULTS AND DISCUSSION}

The dynamics of acid formation during the coagulation of milk with the addition of low-esterified amidated pectin - commercial, or isolated from celery, in a quantity of 1-3 g. $\mathrm{kg}^{-1}$ was researched. The results obtained on the dynamics of the indicators active acidity $(\mathrm{pH})$ and titratable acidity (TA), expressed as \% lactic acid (\% l.a.) during coagulation (min), are presented in Table 1.

Table 1 Dynamics of acid formation, depending of the time of coagulation of milk with the addition of low-esterified amidated pectin

\begin{tabular}{|c|c|c|c|c|c|c|c|c|c|c|c|c|c|c|}
\hline \multirow{3}{*}{$\begin{array}{l}\text { Time, } \\
\text { min }\end{array}$} & \multicolumn{2}{|c|}{ Control sample } & \multicolumn{6}{|c|}{$\begin{array}{l}\text { Concentration of low-esterified amidated pectin - } \\
\text { commercial, g. } \mathrm{kg}^{-1}\end{array}$} & \multicolumn{6}{|c|}{$\begin{array}{l}\text { Concentration of low-esterified amidated pectin from } \\
\text { celery g. } \mathrm{kg}^{-1}\end{array}$} \\
\hline & \multicolumn{2}{|c|}{0} & \multicolumn{2}{|c|}{1} & \multicolumn{2}{|c|}{2} & \multicolumn{2}{|c|}{3} & \multicolumn{2}{|c|}{1} & \multicolumn{2}{|c|}{2} & \multicolumn{2}{|c|}{3} \\
\hline & $\begin{array}{l}\text { TA, \% } \\
\text { 1.a. }\end{array}$ & $\mathrm{pH}$ & $\begin{array}{c}\text { TA, \% } \\
\text { 1.a. }\end{array}$ & $\mathrm{pH}$ & $\begin{array}{l}\text { TA, \% } \\
\text { 1.a. }\end{array}$ & $\mathrm{pH}$ & $\begin{array}{l}\text { TA, \% } \\
\text { 1.a. }\end{array}$ & $\mathrm{pH}$ & $\begin{array}{l}\text { TA, \% } \\
\text { 1.a. }\end{array}$ & $\mathrm{pH}$ & $\begin{array}{l}\text { TA, \% } \\
\text { 1.a. }\end{array}$ & $\mathrm{pH}$ & $\begin{array}{l}\text { TA, \% } \\
\text { 1.a. }\end{array}$ & $\mathrm{pH}$ \\
\hline $0 \pm 1$ & $\begin{array}{c}0.198 \pm \\
0.009^{\mathrm{a}} \\
\end{array}$ & $\begin{array}{c}6.6 \pm \\
0.1^{\mathrm{a}} \\
\end{array}$ & $\begin{array}{c}0.189 \pm \\
0.009^{\mathrm{a}} \\
\end{array}$ & $\begin{array}{c}6.6 \pm \\
0.1^{\mathrm{a}} \\
\end{array}$ & $\begin{array}{c}0.198 \pm \\
0.009^{\mathrm{a}} \\
\end{array}$ & $\begin{array}{c}6.6 \pm \\
0.1^{\mathrm{a}} \\
\end{array}$ & $\begin{array}{c}0.189 \pm \\
0.009^{\mathrm{a}} \\
\end{array}$ & $\begin{array}{c}6.5 \pm \\
0.1^{\mathrm{a}} \\
\end{array}$ & $\begin{array}{c}0.225 \pm \\
0.009^{\mathrm{b}}\end{array}$ & $\begin{array}{c}6.4^{ \pm} \\
0.1^{\mathrm{a}} \\
\end{array}$ & $\begin{array}{c}0.225 \pm \\
0.009^{\mathrm{b}}\end{array}$ & $\begin{array}{c}6.3 \pm \\
0.1^{\mathrm{b}} \\
\end{array}$ & $\begin{array}{c}0.234 \pm \\
0.009^{\mathrm{c}} \\
\end{array}$ & $\begin{array}{l}6.3 \pm \\
0.1^{\mathrm{b}} \\
\end{array}$ \\
\hline $30 \pm 2$ & $\begin{array}{c}0.225 \pm \\
0.009^{\mathrm{a}}\end{array}$ & $\begin{array}{l}6.5 \pm \\
1.0^{\mathrm{a}}\end{array}$ & $\begin{array}{c}0.198 \pm \\
0.009^{\mathrm{b}}\end{array}$ & $\begin{array}{c}6.5 \pm \\
0.1^{\mathrm{a}} \\
\end{array}$ & $\begin{array}{c}0.225 \pm \\
0.009^{\mathrm{a}}\end{array}$ & $\begin{array}{c}6.4 \pm \\
0.1^{\mathrm{a}} \\
\end{array}$ & $\begin{array}{c}0.225 \pm \\
0.009^{\mathrm{a}}\end{array}$ & $\begin{array}{c}6.5 \pm \\
0.1^{\mathrm{a}}\end{array}$ & $\begin{array}{c}0.252 \pm \\
0.009^{\mathrm{c}}\end{array}$ & $\begin{array}{c}6.4 \pm \\
0.1^{\mathrm{a}} \\
\end{array}$ & $\begin{array}{c}0.261 \pm \\
0.009^{\mathrm{d}}\end{array}$ & $\begin{array}{c}6.3 \pm \\
0.1^{\mathrm{b}} \\
\end{array}$ & $\begin{array}{c}0.270 \pm \\
0.009^{\mathrm{d}}\end{array}$ & $\begin{array}{c}6.3 \pm \\
0.1^{\mathrm{b}} \\
\end{array}$ \\
\hline $60 \pm 3$ & $\begin{array}{c}0.225 \pm \\
0.009^{\mathrm{a}}\end{array}$ & $\begin{array}{c}6.5 \pm \\
0.1^{\mathrm{a}}\end{array}$ & $\begin{array}{c}0.216 \pm \\
0.009^{\mathrm{a}}\end{array}$ & $\begin{array}{c}6.4 \pm \\
0.1^{\mathrm{a}}\end{array}$ & $\begin{array}{c}0.261 \pm \\
0.009^{\mathrm{b}}\end{array}$ & $\begin{array}{c}6.4 \pm \\
0.1^{\mathrm{a}}\end{array}$ & $\begin{array}{c}0.252 \pm \\
0.009^{\mathrm{b}}\end{array}$ & $\begin{array}{c}6.4 \pm \\
0.1^{\mathrm{a}}\end{array}$ & $\begin{array}{c}0.270 \pm \\
0.009^{\mathrm{b}}\end{array}$ & $\begin{array}{c}6.3 \pm \\
0.1^{\mathrm{b}}\end{array}$ & $\begin{array}{c}0.261 \pm \\
0.009^{\mathrm{b}}\end{array}$ & $\begin{array}{l}6.2 \pm \\
0.1^{\mathrm{b}}\end{array}$ & $\begin{array}{c}0.288 \pm \\
0.009^{\mathrm{c}}\end{array}$ & $\begin{array}{l}6.2 \pm \\
0.1^{\mathrm{b}}\end{array}$ \\
\hline $90 \pm 2$ & $\begin{array}{c}0.279 \pm \\
0.018^{\mathrm{a}}\end{array}$ & $\begin{array}{c}6.3 \pm \\
0.1^{\mathrm{a}}\end{array}$ & $\begin{array}{c}0.243 \pm \\
0.009^{\mathrm{b}}\end{array}$ & $\begin{array}{l}6.2 \pm \\
0.1^{\mathrm{b}}\end{array}$ & $\begin{array}{c}0.288 \pm \\
0.009^{\mathrm{a}}\end{array}$ & $\begin{array}{l}6.2 \pm \\
0.1^{\mathrm{b}}\end{array}$ & $\begin{array}{c}0.315 \pm \\
0.009^{c}\end{array}$ & $\begin{array}{l}6.2 \pm \\
0.1^{\mathrm{b}}\end{array}$ & $\begin{array}{c}0.387 \pm \\
0.009^{\mathrm{d}}\end{array}$ & $\begin{array}{l}6.1 \pm \\
0.1^{\mathrm{b}}\end{array}$ & $\begin{array}{c}0.333 \pm \\
0.009^{\mathrm{e}}\end{array}$ & $\begin{array}{l}6.1 \pm \\
0.1^{\mathrm{b}}\end{array}$ & $\begin{array}{c}0.333 \pm \\
0.009^{\mathrm{e}}\end{array}$ & $\begin{array}{l}6.1 \pm \\
0.1^{\mathrm{b}}\end{array}$ \\
\hline $120 \pm 3$ & $\begin{array}{c}0.315 \pm \\
0.009^{\mathrm{a}}\end{array}$ & $\begin{array}{c}6.3 \pm \\
0.1^{\mathrm{a}} \\
\end{array}$ & $\begin{array}{c}0.351 \pm \\
0.009^{\mathrm{b}}\end{array}$ & $\begin{array}{c}6.1 \pm \\
0.1^{\mathrm{b}}\end{array}$ & $\begin{array}{c}0.450 \pm \\
0.009^{\mathrm{c}}\end{array}$ & $\begin{array}{c}5.8 \pm \\
0.1^{\mathrm{c}} \\
\end{array}$ & $\begin{array}{c}0.423 \pm \\
0.009^{\mathrm{d}}\end{array}$ & $\begin{array}{c}6.0 \pm \\
0.1^{\mathrm{c}} \\
\end{array}$ & $\begin{array}{c}0.486 \pm \\
0.009^{\mathrm{e}}\end{array}$ & $\begin{array}{c}5.8 \pm \\
0.1^{\mathrm{c}} \\
\end{array}$ & $\begin{array}{c}0.378 \pm \\
0.009^{\mathrm{e}}\end{array}$ & $\begin{array}{c}5.8 \pm \\
0.1^{\mathrm{c}} \\
\end{array}$ & $\begin{array}{c}0.432 \pm \\
0.009^{\mathrm{d}}\end{array}$ & $\begin{array}{r}5.8 \pm \\
0.1^{\mathrm{c}} \\
\end{array}$ \\
\hline $150 \pm 3$ & $\begin{array}{c}0.459 \pm \\
0.018^{\mathrm{a}} \\
\end{array}$ & $\begin{array}{c}6.0 \pm \\
0.1^{\mathrm{a}} \\
\end{array}$ & $\begin{array}{c}0.441 \pm \\
0.009^{\mathrm{a}} \\
\end{array}$ & $\begin{array}{c}5.8 \pm \\
0.1^{\mathrm{a}} \\
\end{array}$ & $\begin{array}{c}0.504 \pm \\
0.009^{\mathrm{b}}\end{array}$ & $\begin{array}{c}5.4 \pm \\
0.1^{\mathrm{b}} \\
\end{array}$ & $\begin{array}{c}0.513 \pm \\
0.009^{\mathrm{b}}\end{array}$ & $\begin{array}{c}5.6 \pm \\
0.1^{\mathrm{b}} \\
\end{array}$ & $\begin{array}{c}0.567 \pm \\
0.009^{c} \\
\end{array}$ & $\begin{array}{c}5.3 \pm \\
0.1^{\mathrm{b}} \\
\end{array}$ & $\begin{array}{c}0.576 \pm \\
0.009^{\mathrm{c}} \\
\end{array}$ & $\begin{array}{c}5.5 \pm \\
0.1^{\mathrm{b}} \\
\end{array}$ & $\begin{array}{c}0.540 \pm \\
0.009^{\mathrm{d}} \\
\end{array}$ & $\begin{array}{c}5.6 \pm \\
0.1^{\mathrm{b}} \\
\end{array}$ \\
\hline $180 \pm 4$ & $\begin{array}{c}0.513 \pm \\
0.009^{\mathrm{a}}\end{array}$ & $\begin{array}{c}5.4 \pm \\
0.1^{\mathrm{a}}\end{array}$ & $\begin{array}{c}0.594 \pm \\
0,009^{\mathrm{b}}\end{array}$ & $\begin{array}{c}5.4 \pm \\
0.1^{\mathrm{a}}\end{array}$ & $\begin{array}{c}0.567 \pm \\
0.009^{\mathrm{c}}\end{array}$ & $\begin{array}{c}5.3 \pm \\
0.1^{\mathrm{a}}\end{array}$ & $\begin{array}{c}0.585 \pm \\
0.009^{\mathrm{c}}\end{array}$ & $\begin{array}{c}5.2 \pm \\
0.1^{\mathrm{a}}\end{array}$ & $\begin{array}{c}0.585 \pm \\
0.009^{\mathrm{c}}\end{array}$ & $\begin{array}{c}5.1 \pm \\
0.1^{\mathrm{a}}\end{array}$ & $\begin{array}{c}0.612 \pm \\
0.009^{d}\end{array}$ & $\begin{array}{c}5.2 \pm \\
0.1^{\mathrm{a}}\end{array}$ & $\begin{array}{c}0.585 \pm \\
0.009^{\mathrm{c}}\end{array}$ & $\begin{array}{c}5.2 \pm \\
0.1^{\mathrm{a}}\end{array}$ \\
\hline $210 \pm 5$ & $\begin{array}{c}0.603 \pm \\
0.009^{\mathrm{a}}\end{array}$ & $\begin{array}{c}5.1 \pm \\
0.1^{\mathrm{a}} \\
\end{array}$ & $\begin{array}{c}0.639 \pm \\
0.009^{\mathrm{b}}\end{array}$ & $\begin{array}{c}5.3 \pm \\
0.1^{\mathrm{a}} \\
\end{array}$ & $\begin{array}{c}0.621 \pm \\
0.009^{\mathrm{b}}\end{array}$ & $\begin{array}{c}5.1 \pm \\
0.1^{\mathrm{a}} \\
\end{array}$ & $\begin{array}{c}0.639 \pm \\
0.009^{\mathrm{b}}\end{array}$ & $\begin{array}{c}5.0 \pm \\
0.1^{\mathrm{a}} \\
\end{array}$ & $\begin{array}{c}0.612 \pm \\
0.009^{\mathrm{a}}\end{array}$ & $\begin{array}{c}5.0 \pm \\
0.1^{\mathrm{a}} \\
\end{array}$ & $\begin{array}{c}0.639 \pm \\
0.009^{\mathrm{b}}\end{array}$ & $\begin{array}{c}5.0 \pm \\
0.1^{\mathrm{a}} \\
\end{array}$ & $\begin{array}{c}0.621 \pm \\
0.009^{\mathrm{b}}\end{array}$ & $\begin{array}{r}5.1 \pm \\
0.1^{\mathrm{a}} \\
\end{array}$ \\
\hline
\end{tabular}

a,b,c,d,e Means with different letters within a row are significantly different $(\mathrm{p}<0.05)$

A marked prolongation of the milk coagulation time from 180 to 210 min was established in the experimental samples. The reported extension of the coagulation process is in direct relation with the increase in osmotic pressure of the culture medium as a result of presence of sucrose at a concentration of 60 g. $\mathrm{kg}^{-1}$, which affects the vital activity of the lactic acid microorganisms. The dynamics of the lactic acid process expressed by the indicators active acidity, titratable acidity and coagulation time of the experimental samples with addition of low-esterified and amidated pectin are close to that of the control sample. The obtained results fully correspond with the studies of other researchers, which indicates that the inhibitory effect of amidated pectin on the acid coagulation of casein in the manufacture of fermented dairy products is observed in values above 2 g. $\mathrm{kg}^{-1}$ (Lara et al., 2004).

An important indicators determining the quality of fermented dairy products are the stability of coagulum and the tendency to syneresis. For this reason, the syneresis of coagulums observed in the control samples and experimenta samples, expressed as amount of separated serum was determined by a centrifugal test.

Table 2 presents the results on the amount of serum in $\mathrm{cm}^{3} \cdot \mathrm{dm}^{-3}$, determined by centrifugal test.

Table 2 Quantity of serum from the coagulum of samples produced by the addition of low-esterified and amidated pectin

\begin{tabular}{|c|c|c|c|c|c|c|c|}
\hline \multirow{2}{*}{$\begin{array}{l}\text { Concentration of low-esterified } \\
\text { amidated pectin, g. } \mathrm{kg}^{-1}\end{array}$} & $\begin{array}{l}\text { Control } \\
\text { Sample }\end{array}$ & \multicolumn{3}{|c|}{ Low-esterified amidated pectin - commercial } & \multicolumn{3}{|c|}{ Low-esterified amidated pectin from celery } \\
\hline & 0 & 1 & 2 & 3 & 1 & 2 & 3 \\
\hline Quantity of serum, $\mathrm{cm}^{3} \cdot \mathrm{dm}^{-3}$ & $300 \pm 10^{\mathrm{a}}$ & $300 \pm 10^{\mathrm{a}}$ & $320 \pm 5^{b}$ & $340 \pm 10^{\mathrm{c}}$ & $300 \pm 10^{\mathrm{a}}$ & $330 \pm 10^{b}$ & $340 \pm 10^{\mathrm{c}}$ \\
\hline
\end{tabular}

$\overline{a, b, c}$ Means with different letters within a row are significantly different $(\mathrm{p}<0.05)$

The results of the centrifugal test on the quantity of serum indicate that the values of this parameter increase with the increase in the concentration of lowesterified amidated pectin. The analysis confirmed the data obtained by Lara $\boldsymbol{e t}$ al. (2004), which found that when the amidation pectin values are in the range of $2-6 \mathrm{~g} \cdot \mathrm{kg}^{-1}$, the quantity of the serum increases. This tendency is explained by the gradual release of calcium ions from the casein aggregates during coagulation, due to a decrease in the $\mathrm{pH}$ values and the electrostatic adsorption of pectin molecules on casein particles. These processes upset the balance of casein-casein, pectin-pectin and casein-pectin bonds in the structure of the protein gel. The obtained results show that the addition of amidated pectin in fermented dairy products leads to an increase in the amount of serum, and it is recommended to use it in practice in a concentration not higher than $1 \mathrm{~g} \cdot \mathrm{kg}^{-1}$. The viscosity (eta) of fermented dairy products depending on the amount and type of used amidated pectin in the range of variation of speed gradient (D) of 0.17 to $72.9 \mathrm{~s}^{-1}$ was determined. The obtained results are presented in Figure 1. 


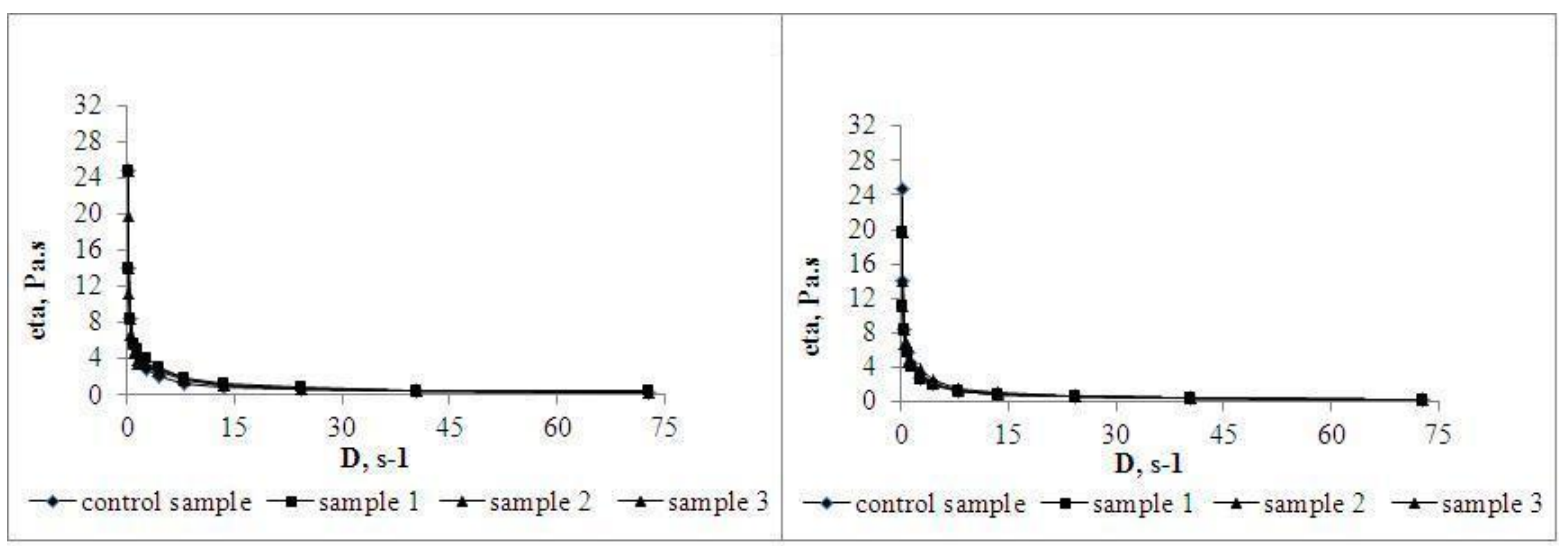

Variant A - a commercial pectin

Variant $B$ - pectin from celery

Figure 1 Viscosity of the resulting fermented dairy products with the addition of low-esterified amidated pectin

The graphically expressed dependencies show that the viscosities of the fermented dairy products with added commercial low-esterified amidated pectin and pectin extracted from celery have values close to those of the control sample. The organoleptic profile (package, appearance, texture, density of coagulum, taste and aroma) of fermented dairy products with added low-esterified amidated pectin from celery and commercial pectin in an amount of 1 to $3 \mathrm{~g} . \mathrm{kg}^{-1}$ was also investigated (Figure 2).
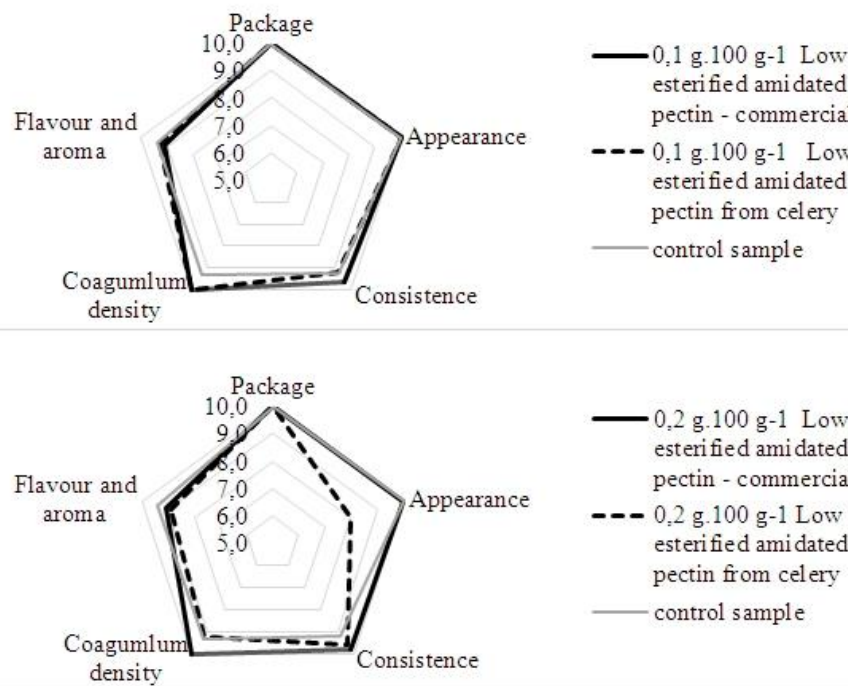

- 0,2 g. $100 \mathrm{~g}-1$ Low esterified amidated pectin - commercial

- - 0,2 g.100 g-1 Low esterified amidated pectin from celery

control sample

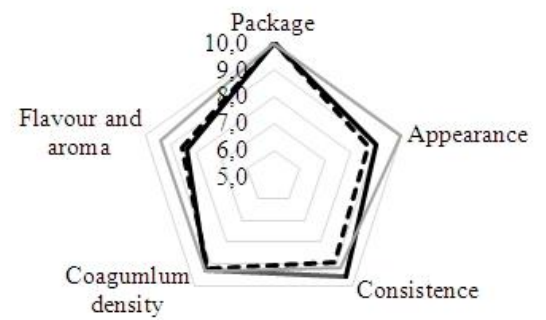

0,3 g. $100 \mathrm{~g}-1$ Low esterified amidated pectin - commercial

- 0,3 g. 100 g-1 Low esterified amidated pectin from celery

control sample

Figure 2 Organoleptic characteristic of lactic acid products with set coagulum and the addition of low-esterified amidated pectin

The obtained results reveal that the highest total score has been awarded to the variant with the addition of amidated pectin in an amount of 1 g. $\mathrm{kg}^{-1}$. In all evaluated indicators - density of coagulum, appearance, texture and flavor, this variant has characteristics similar to those of the control sample. It was found that the organoleptic characteristics of fermented dairy products with low-esterified amidated pectin extracted from celery are similar to those of commercial pectin. Given these properties, low-esterified amidated pectin isolated from Bulgarian celery may be used as an alternative to commercial pectins.

\section{CONCLUSION}

Low-esterified amidated pectin isolated from celery can be used successfully for the preparation of fermented dairy products enriched with soluble dietary fibers It was found that the addition of amidated pectin from celery in an amount exceeding 1 g. $\mathrm{kg}^{-1}$ deteriorates the organoleptic characteristics of the product, while the indicator viscosity of the finished product remains analogous to that of the control sample. Therefore, the recommended low-esterified amidated pectin concentrations for use in fermented dairy products should not exceed the established limits.

Acknowledgements: This research was financially supported by The Scientific Investigation Section Project 3/13-H, fund "Science", University of Food Technologies, Plovdiv, Bulgaria. We gratefully acknowledge material support from Herbstreith \& Fox, Germany.

\section{REFERENCES}

BEENA, A. 2000. Healthbenefits of fermented milks, In: ICAR. Winter school on recent developments in fermentation of milk, Kerela Agricultural University, 88 95.

BULGARIAN NATIONAL STADARD 12:2010 - Bulgarian yogurt, [in Bulgarian].

COMBO, A., AGUEDO, M., PAQUOT, M. 2011. Les oligosaccharides pectiques: production et applications possible [Pectin oligosaccharides: production and possible applications], 15(1): 153-164, [in French].

ISO 6091:2010 (IDF 86:2010). Determination of titratable acidity (Reference method).

KHURANA, H., KANAWJIA, S. 2007. Recent Trends in Development of Fermented Milks. Current Nutrition \& Food Science, 3:91108. http://dx.doi.org/10.2174/1573401310703010091

KONDRATENKO, M., SIMOV, Z. 2003. Bulgarian yoghurt. Association of milk producers in Bulgaria, 149 - 176, [in Bulgarian]

KUNCHEVA, M., PAVlOVA, K., PANCHEV, I., DOBREVA, S. 2007.

Emulsifying power of mannan and glucomannan produced by yeasts. International Journal of Cosmetic Science, 29(5):377384. http://dx.doi.org/10.1111/j.1468-2494.2007.00393.x

LARA, M., LAU, K., DICKINSON, E. 2004. Effects of low-methoxyl amidated pectin and ionic calcium on rheology and microstructure of acid-induced sodium caseinate gels. Food Hydrocolloids, 18(2):271-281 http://dx.doi.org/10.1016/s0268-005x(03)00083-3

MAROZIENE, C., KRUIF, G. 2000. Interaction of pectin and casein micelles Food Hydrocolloids, 14(4):391-394. http://dx.doi.org/10.1016/s0268 005x(00)00019-9

RAMASWAMY, H., BASAK, S. 1992. Pectin and raspberry concentrate effects on the rheology of stirred commercial yoghurt. Journal of Food Science, 57:357360. http://dx.doi.org/10.1111/j.1365-2621.1992.tb05494.x

URESTI, R., ARIAS, N., CABRIALES, J., RAMIREZ, J., VAZQUEZ, M. 2003. Use of amidated low methoxyl pectin to produce fish restructured products. Food Hydrocolloids, 17:171-176. http://dx.doi.org/10.1016/s0268-005x(02)00049-8 VLASEVA, R. 2014. Functional dairy products. Academic Publishing of University of Food Technologies, 89-97, [in Bulgarian]. 